\title{
The Absent Image
}





\section{The Absent Image}

LACUNAE IN MEDIEVAL BOOKS

Elina Gertsman

THE PENNSYLVANIA STATE UNIVERSITY PRESS

University Park, Pennsylvania 
Publication of this book has been aided by a grant from the Millard Meiss Publication Fund of CAA.

\section{$\mathrm{CA}_{\mathbf{A}} \mathrm{MM}$}

Library of Congress Cataloging-in-Publication Data

Names: Gertsman, Elina, author.

Title: The absent image : lacunae in medieval books / Elina Gertsman.

Description: University Park, Pennsylvania : The Pennsylvania State University Press, [2021] | Includes bibliographical references and index.

Summary: "Explores the late medieval concepts of absence and void, with a special focus on the materiality of emptiness in later medieval manuscripts"Provided by publisher.

Identifiers: LCCN 2020058331 | ISBN 9780271087849 (cloth)

Subjects: LCSH: Illumination of books and manuscripts, Medieval. |

Manuscripts, Medieval. | Absence in art. | Emptiness (Philosophy) in art. |

Nothing (Philosophy) in art.

Classification: LCC ND2920 .G47 2021 | DDC 745.6/700902-dc23

LC record available at https://lccn.loc.gov/2020058331

Copyright (C) 2021 The Pennsylvania State University

All rights reserved

Printed in China

Published by The Pennsylvania State University Press,

University Park, PA 16802-1003

The Pennsylvania State University Press is a member of the Association of University Presses.

It is the policy of The Pennsylvania State University Press to use acid-free paper. Publications on uncoated stock satisfy the minimum requirements of American National Standard for Information Sciences-Permanence of Paper for Printed Library Material, ANSI Z39.48-1992. 
In loving memory of my father,

Julius P. Gertsman,

whose death left behind an inexpressible emptiness 
